\title{
EXPLORING THE FINANCE AND GROWTH RELATIONSHIP FOR EMERGING MARKET ECONOMIES
}

\author{
Hsin-Yu Liang* \\ Feng Chia University, Taiwan \\ lianghy@fcu.edu.tw \\ Alan Reichert\# \\ Cleveland State University, USA \\ a.reichert@csuohio.edu
}

July 2011

\begin{abstract}
This study focuses on alternative ways to measure financial sector development and the external factors that both directly and indirectly influence economic growth. The empirical results based upon panel data from 1985 to 2003 for a sample of emerging countries suggest three major conclusions. First, by including a range of alternative financial sector development measures and a variety of external policy-related factors in the model, the importance of supplying basic liquidity services, as measured by M3, becomes less important for emerging countries. Second, the empirical results suggest that while a basic level of deposit insurance protection might prove stabilizing for emerging economies, excessive levels of insurance may promote undue risk. Third, several competitive market structure and regulatory variables designed to measure efficiency in the intermediation process, such as net interest margin, and managerial efficiency as measured by overhead costs, are found to have a statistically significant, and in certain cases, unexpected impacts.
\end{abstract}

\section{Keywords}

Financial development, legal structure, regulation, law, technology, deposit insurance, finance and growth nexus

\footnotetext{
* Prof Hsin-Yu Liang is assistant professor in the International Trade Department, Feng Chia University, Taiwan.

\# Prof Alan Reichert is professor in the Department of Finance, Cleveland State University, USA.
} 


\section{INTRODUCTION}

Policymakers are interested in promoting global economic growth and are particularly interested in learning how financial sector development can accelerate the process. This study focuses on alternative ways to measure financial sector development (FSD) and the external factors that both directly and indirectly influence the relationship between financial sector development and economic growth. Examples of such factors include the nature of a country's legal structure and property right laws, foreign bank entry restrictions, degree of bank privatization and market concentration, presence of deposit insurance, and degree of technological innovation. While previous studies have identified and modelled individual external factors, this study is the first study to link, in a rigorous and comprehensive way, a wide range of external factors, alternative measures of financial sector development, and economic growth.

A century ago, Schumpeter (1911) argued that the services provided by financial intermediaries - mobilising savings, evaluating projects, managing risk, monitoring managers, and facilitating financial transactions - are essential for innovation and economic development. King and Levine (1993) found evidence to support Schumpeter's view that financial intermediaries facilitate technological innovation, foster a more efficient allocation of resources and thereby accelerate long-run economic growth by reducing risk. The financial structure of a country consists of the institutions, financial technology, and "rules-of-thegame" that define how financial activity is organized at any given point in time. Prior work by Levine $(1998,1999)$ and Levine, Loayza, and Beck (2000) suggests that future research should include, in addition to proper measures of financial sector development, various measures of the legal, supervisory, and regulatory factors that influence economic growth.

Using panel data from 1985 to 2003 for a sample of developing countries, this study focuses on modelling alternative definitions of FSD and the external factors that both directly and indirectly influence the relationship between FSD and economic growth. Such factors include the nature of a country's legal structure and property right laws, foreign bank entry restrictions, degree of bank privatization and market concentration, presence of deposit insurance, and degree of technological innovation. The remainder of this paper is organized as follows. Section II reviews the literature on the relationship between FSD and economic growth. Section III discusses the methodology and the empirical model. Section IV presents the empirical findings, while Section V summarizes the conclusions.

\section{LITERATURE REVIEW}

The general hypothesis being tested in this study is that a comprehensive definition of financial sector development is important and that a country's financial, legal, regulatory structure, and technological development, all work together to influence economic growth. More specifically, the first hypothesis states that a direct relationship exists between a vector of external legal, regulatory, and technology factors and a country's rate of economic growth. The second hypothesis states that these external factors may indirectly impact a country's rate of economic growth as they work to either enhance or diminish the linkage between FSD and economic growth. Hence, these external factors may potentially generate both a direct and an indirect (or interactive effect), between FSD and economic growth. For example, in the area of bank regulation, deposit insurance programs may have either a negative or positive impact upon 
economic efficiency and growth depending upon the ability of bank supervision to control excessive risking-taking encouraged by potentially mispriced deposit insurance programs. Thus, the strength of a country's bank supervision and regulation many affect the impact of deposit insurance on risk-taking and economic growth. Based upon previous research work and the theoretical requirements of macro-economic growth models, the literature review is organized around seven major issues: 1) alternative measures of financial sector development, 2) legal environment, 3) government regulation, 4) competitive market structure, 5) public vs. private sector governance, 6) information and communication technology, and 7) household and small business access to financial services.

\subsection{Alternative measures of FSD}

Goldsmith (1969) was the first to examine the relationship between financial sector development and economic growth under the assumption that the size of the financial system is a proxy for the quality of financial services provided. Similarly, in a more recent article Odedokun (1996) measured a country's level of financial sector development using a broad measure of financial intermediation such as country's money supply (M3). Levine (1998) measured banking sector development as the ratio of aggregate bank credit divided by GNP. Using the same econometric approach, Levine (1999) expanded his previous work using four alternative measures of FSD: 1) the ratio of liquid liabilities to GDP, 2) the ratio of bank assets to total bank and central banks assets, 3) bank credits /total domestic credits, and 4) bank private credits/GDP. This study builds upon the definitions employed in this last paper and the basic modelling framework developed in the Odedokun study.

\subsection{Legal environment}

In terms of the legal environment, La Porta et al. (1997b) found that whether a country's commercial law is based on British, French, German, or Scandinavian law has important implications for economic growth. Levine $(1998,1999)$ also found a positive correlation between legal origin, financial sector development, and a country's rate of economic growth. DemirgucKunt and Maksimovic (2002) argue that a strong legal system provides certain countries with a comparative advantage regarding the quality of both their banking system and securities markets. On the other hand, they suggest that through a combination of effective bank regulation and strong bank competition, deficiencies in the legal system can be at least partially rectified. While a legal structure which provides strong creditor rights and enforcement procedures is necessary to support a modern banking system, it is even more critical to the development of debt and equity markets.

The complementary and substitute roles between stock markets and the banking sector raise the question as to precisely how law, regulation, and macroeconomic factors interact to promote stock markets, banking sector development, and economic growth. Stulz (2000) argues that the optimal financing of an investment project requires the reduction of information asymmetries between the borrowers and lenders. In countries with well-established legal structures and enforcement procedures, fewer information asymmetries exist, leading to a reduction of hidden claims on cash flows. However, in countries with limited creditor rights and/or lax legal enforcement, investors have little chance of receiving the promised cash flows if the borrower decides not to pay. In the case of the capital markets, information asymmetry between investors and entrepreneurs often makes it nearly impossible for the entrepreneur to issue shares directly to investors. Therefore, the primary way to obtain financing is from banks, commercial finance 
companies, and venture capitalists.

To investigate this issue, Rajan and Zingales (2001) conducted an analysis of the arm's length market-based financial systems versus relationship-based banking systems. They find that a mix of both systems is probably best for most countries. Furthermore, they suggest that improvements in accounting, disclosure, legal and bankruptcy codes will help reduce risk and are necessary to support a large banking system and financial markets. More recently, Liang and Reichert (2007) found that a shift from bank-based to market-based financial sector drivers of economic growth ultimately takes place for both developed and less developed countries. In a related study, Cheng and Degryse (2010) compare the impact of the growth of bank and nonbank financial institutions in China from 1995-2003. They find that banking sector development, and in particular bank credit, generates local economic growth. At the same time, they find little relationship between development in the non-bank sector and economic growth. They attribute this disparity to the fact that recent financial reforms, such as market entry deregulation and liberalization, have benefited the bank sector more directly.

\subsection{Government regulation}

In terms of regulation, extensive literature exists on the role of government in the financial sector. For example, Barth et al. (2001a, 2004) conducted a survey of 107 countries to close the information gap linking regulation and bank performance. Their studies found that regulatory policies which: 1) force accurate information disclosure 2) promote private-sector control of banks, and 3) foster incentives for private agents, such as credit rating agencies, to exert corporate control, all work together to promote banking sector performance and stability.

On the other hand, direct government involvement in the banking system has the potential to adversely affect general economic welfare. Caprio and Levine (2002) state that although the reliability of the payment system and threat of monopoly power are important reasons for government intervention, the most important reason for intervention is the information asymmetry between various stakeholders. For example, deposit insurance and other bank solvency protections often reduce the effect of information asymmetries between depositors and bank management. However, banks can exploit the system as they seek to maximize the value of the put option associated with deposit insurance by taking on excessively risky activities (i.e., the moral hazard problem). Shareholders benefit from higher risk-return portfolios since they have limited liability, while taxpayers bear the cost of excessively risky decisions. Furthermore, deposit insurance reduces the incentives for debt holders to monitor bank activities. Historically, following the implementation of a national deposit insurance system in the United States in 1934, other countries were slow to adopted similar insurance systems. During the next 30 years only six deposit insurance programs were established. Since the mid-1960's adoption accelerated and 70 countries had developed deposit insurance programs by the end of 2000, and the trend is forecasted to continue (Barth et al., 2004).

\subsection{Competitive market structure}

The theory of monopolistic competition suggests that regulatory impediments to competition and the exercise of monopolistic power create an environment in which a few large banks may hinder competition, reducing bank efficiency, and lower consumer welfare. Thus, according to the structure-conduct-performance model, high levels of market concentration may be a signal of an uncompetitive and inefficient market. On the other hand, the "relative efficiency 
hypothesis" argues that more efficient banks operate with lower costs and achieve greater market share through economies of scale and scope. In this case, a highly competitive market may produce a concentrated yet efficient banking system. Thus the role of market structure is somewhat unclear.

For example, Classens and Klingebiel (2000) point out that regulatory restrictions on bank and non-bank mergers limit the potential benefits from economies of scale and scope. Furthermore, fewer regulatory restrictions can increase franchise value and lead to more prudent management behaviour. In addition, a broader range of activities may enable banks to diversify income streams and potentially improve bank stability. To illustrate, two recent papers (Wall et al, 2008 and Reichert et al, 2008) explore the potential benefits of combining commercial banking and commerce in the US. Their analysis suggests that while there may be risks associated with merging banking and commerce, the potential benefits associated with access to deeper management talent and additional capital may improve the stability of the financial sector. On the other hand, a number of reasons for restricting bank activities are summarized by Barth et al. (2004). First, they see a potential conflict of interest when banks engage in diverse financial services, such as, securities and insurance underwriting and real estate investment. Second, moral hazard associated with deposit insurance is increased when a wide range of financial activities are permitted. Third, large complex bank organizations are difficult to monitor. Fourth, banks may become so politically and economically important that a "too-big-to-discipline" doctrine comes into play. Finally, large financial conglomerates may reduce competition and efficiency through their exercise of market power.

Fu and Heffernan (2007) explored the effects of regulatory reform on market structure and performance in the Chinese banking system from 1985 to 2002. They tested the structureconduct-performance and relative market power hypotheses, along with the "quiet life" hypotheses associated with monopolies. They find that the reforms are correlated with their sample of banks becoming more $X$-efficient but found no significant changes in market structure. In addition, the strict regulation on bank expansion and interest rate controls eliminate the opportunity for monopoly profits and a "quiet life".

\subsection{Public vs. private sector governance}

In terms of public versus private sector involvement the literature is once again divided. For example, Gerschenkron (1962) argued that government ownership of banks overcomes capital market failures, allows the banking sector to exploit positive externalities, and promotes investment in strategically important projects. In contrast, Shleifer and Vishny (1998) argued that governments do not have sufficient incentives to ensure socially optimal investment and that government ownership facilitates the financing of politically, versus economically, attractive projects. La Porta et al. (2002) found that countries with higher initial levels of government ownership of banks tend to have less developed financial sectors and slower economic growth. Barth et al. (2001a) examined government ownership data and find that greater public ownership is generally associated with less efficient and less well-developed financial systems. Examining a similar issue, Clark, Cull, and Shirly (2005) found that government efforts to privatize the banking sector usually improves bank efficiency, and that gains to privatization are much more extensive and long-lasting when: 1) the government relinquishes full control, 2) when banks are sold to strategic investors, 3 ) when foreign banks are allowed to participate in the privatization process, and 4) when the government does not restrict competition. 
Megginson and Sutter (2006) surveyed a large number of empirical studies that analyse the impact of privatization in developing countries. While the studies generally found that privatization improves firm performance and lowers leverage, the degree of improvement is positively influenced by: 1) industry-specific sectors, with regulated industries reporting the greatest improvement, 2) whether or not operational restructuring took place following privatization, and 3 ) the degree of shareholder protection afforded by the law. In a more recent study, using World Bank privatization data for 56 banks from 10 countries, Otchere (2009) found evidence that privatization in developing countries has encouraged additional risk-taking by banks as measured by an increase in non-performing loans. Furthermore, consistent with the competitive effects hypothesis, the data on 174 rival banks suggests that they view privatization as likely to reduce their economic rents. Finally, Cull and Spreng (2011) examined the progress made in Tanzania following the privatization of the National Bank of Commerce. The bank was split into two separate banks, the larger "new" National Bank of Commerce and the National Microfinance Bank, which assumed many of the bank's retail branches. The study found that the ultimate sale of both banks to a large foreign proved to be highly beneficial to the subsequent growth and profitability of both banks.

\subsection{Information and communication technology}

In terms of information and communication technology (ICT), Reichert (1995) examined the impact of the adoption of the personal computer on the decision making process for the largest US firms. He found that this technology has dramatically changed the precision and timeliness of information within large companies. Stiroh (1999) found that investment and innovation in this area has a positive and significant impact on financial sector productivity. A higher level of ICT investment contributes to greater market flexibility and enhanced transparency, which leads to productivity growth. In the non-financial sector, Houben and Kakes (2002) concluded that ICT promotes more effective inventory management and faster information flows, which contribute to more stable economic growth. At the same time, ICT-driven productivity growth varies considerably between countries. These cross-country differences may be linked to differences in financial structure, as certain financing methods may be better suited to stimulate ICT entrepreneurial investments. Stiroh (2002) studied the relationship between production spillovers and network effects related to ICT and the "New Economy" using US data. The author found little evidence that capital investment in ICT is correlated with total factor productivity growth as implied in the "New Economy" hypothesis, although ICT it is positively correlated with average labour productivity. O'Mahony and Vecchi (2005) explored the impact of ICT on real output for the US and the UK using panel data from 1976 to 2000. Pooling the data and employing dynamic panel estimation techniques, the authors found a positive and significant impact, especially for the US.

\subsection{Financial sector access}

In a very real sense many of the factors mentioned above relate to the issue of financial access, which has recently received considerable research attention. For example, Beck and DemirgucKunt (2008) reviewed the recent research work which focuses on ways of measuring and quantifying the impact of household and small business access to financial services on economic development. Beck, Demirguc-Kunt, and Martinez Peria (2008) developed measures of barriers to financial access across various countries and explore their correlation with measures of outreach. For example, minimum account and loan balances, account fees and 
documentation are negatively correlated with outreach or access. More competitive banking systems and market-based supervisory policies are correlated with lower barriers, while government-owned banking systems are associated with higher access barriers. Beck and de la Torre (2007) studied the issue of financial access by identifying various supply and demand constraints. They define an "access possibilities frontier" to identify the optimal level of services and distinguish between payment and savings services versus credit services. Finally, from a methodology perspective, Beck et al. (2007) developed new aggregate measures of banking sector financial outreach, such as the number of loan and deposit accounts adjusted for population and the average loan and deposit size relative to GDP per capita. These macro indicators are effective predictors of harder-to-collect micro household and small business data and prove to be related to the traditional measures of financial sector depth.

\section{MODEL AND DATA}

\subsection{Model}

The literature surrounding Solow-type growth models employed in this paper is voluminous, and a complete review is beyond the scope of this paper. Some recent papers include Alfo, Trovato, and Waldman (2008), who examined cross-country differences to improve an extended Solow growth model, while Phillips (2007) examined growth convergence and allows for heterogeneous technology. Jeong and Townsend (2007) examined the sources of total factor productivity, including financial "deepening" and sectoral-Solow model residuals. Finally, Ding and Knight (2009) employed an augmented Solow model to evaluate China's dramatic economic growth. The current study adopts Odedokun's (1996) neo-classical aggregate production function model to examine the impact of external factors on economic growth. In addition to a single measure of financial sector development (M3), Odedokun's model includes a number of other relevant macro-economic factors. Odedokun's model is a "supply leading" model, which assumes that growth in the financial sector promotes growth in the real sector, in contrast to a "demand following" model, which assumes that economic development stimulates growth in the demand for financial services. The most general form of Odedokun's model is specified as:

$$
Y_{t}=f\left(L_{t}, K_{t}, F_{t}, Z_{t}\right)
$$

where $Y$ represents aggregate output or real GDP; $L$ represents labour; $K$ indicates the capital stock; $F$ is a measure of financial sector development (FSD); $Z$ represents a vector of other factors, such as the level of exports $(X)$, that can be regarded as inputs in the aggregate production process, and " $t$ " represents a specific year. Using changes in the variables rather than levels, Odedokun's empirical model is given in equation (2):

$$
\dot{Y}_{t}=B_{0}+B_{1} \dot{L}_{t}+B_{2}(I / Y)_{t}+B_{3} \dot{F}_{t}+B_{4} \dot{X}_{t}+u_{t}
$$

where $I$ represents real investment and the symbol $(\cdot)$ indicates the annual rate of growth of the relevant variables. In Odedokun's model the degree and directional effect of FSD on economic growth rate is measured by the regression coefficient $B_{3}$ on $F_{l t}$. Based on its flexibility and widespread use in the literature, this study extends the basic Odedokun model to estimate the impact of a wide range of external factors on economic growth. More specifically, we extend Odedokun's model by including alternative measures of financial sector development, external variables (i.e., measures of law, regulation and technology), various interaction terms, and 
country-specific dummy variables (fixed effects). Table 1 presents a more detailed description of how the variables in the Odedokun model are calculated. However, due to a high degree of multicollinearity between these variables they cannot all be directly entered in the model. An alternative method is to use various combinations of these variables in the model. Principal components analysis is employed to extract orthogonal factors that capture most of the variability in the underlying data.

\section{TABLE 1: Variables from World Bank 2006 indicators}

\begin{tabular}{|c|c|}
\hline Definition & Abbreviation \\
\hline Population growth (annual\%) & Pop \\
\hline Gross fixed capital formation (constant 2000 US\$) & Investment \\
\hline Exports of goods and services (constant 2000 US\$) & Export \\
\hline Liquid liabilities (M3) as\% of GDP & $M 3 \%$ \\
\hline GDP (constant 2000 US\$) & GDP \\
\hline Model variables & Calculation \\
\hline a) $\dot{Y}$ & {$[\log (G D P)-\log (G D P(-1))]$} \\
\hline b) $\dot{L}$ & Pop/100 \\
\hline c) $I / Y$ & [Investment/GDP] \\
\hline d) $\dot{X}$ & {$[\log (E x p o r t)-\log (E x p o r t(-1)]$} \\
\hline \multirow[t]{2}{*}{ e) $\dot{F}$} & {$[\log (f s d)-\log (f s d(-1))]$} \\
\hline & where $f s d=(M 3 \% / 100) \star G D P$ \\
\hline
\end{tabular}

\section{Source: Own calculations}

Thus, the following model is estimated in a panel data framework (note: bold terms represent vectors of variables):

$$
\begin{aligned}
& \dot{Y_{l t}}=b_{0}+b_{1} \dot{L}_{l t}+b_{2}(I / Y)_{i t}+b_{3} \dot{X_{l t}}+b_{4} \dot{F}_{l t}+\mathbf{B}_{\mathbf{1}}{ }^{\prime} \mathbf{E}_{\mathbf{i t}}+\dot{\mathbf{F}}_{\mathbf{i t}} \mathbf{B}_{\mathbf{2}}{ }^{\prime} \mathbf{E}_{\mathbf{i t}}+\mathbf{B}_{\mathbf{3}}{ }^{\prime} \mathbf{F S D}_{\mathbf{i t}}+ \\
& \dot{\mathbf{F}}_{\mathbf{1 t}} \mathbf{B}_{\mathbf{4}}{ }^{\prime} \mathbf{F} \dot{\mathbf{S D}}_{\mathbf{1 t}}+u_{i t}
\end{aligned}
$$

where,

$\dot{Y_{l t}} \quad=$ economic growth measured as the annual growth rate of real GDP.

$\dot{L_{l t}} \quad=$ labour force growth proxied by the annual rate of growth of the entire population.

$(I / T)=$ gross nominal fixed capital formation (I) divided by nominal GDP (y).

$\dot{X_{l t}}=$ the annual rate of growth rate of real exports of goods and services.

$F_{l t}=$ the annual growth rate of liquid liabilities (M3) as used by Odedokun.

$F \dot{S D}_{l t}=$ represents two complementary measures of financial sector development:

$\mathbf{E}_{\text {it }}=$ a vector of ten external exogenous factors as follows:

$L \varepsilon G A L=a$ measure of country's legal structure and property rights

DEPOSITINS = deposit insurance coverage divided by per capita GDP 
BKCONCEN = combined assets of the three largest banks divided by total banking assets

NIM = banking system's net interest income divided by total interest bearing assets

OHCOST = aggregate value of the banking systems overhead costs divided by total assets

BKPRIVAT = percentage of deposits held in privately owned banks, measured in deciles

FGENTRY= foreign banks' share of total banking sector assets, measured in deciles

BKFREE = Bank Freedom Index regarding the permissibility of mixing bank and commerce

TECHEXP = Computer communications and other service (\% of commercial service exports)

TECHIMP = Computer, communications and other service (\% of commercial service imports)

$\mathbf{B}_{\mathbf{1}}{ }^{\prime}=$ a vector of $n_{1}$ regression coefficients, which reflect the direct impact of $n_{1}$ external factors on economic growth,

$\mathbf{B}_{3}{ }^{\prime}=$ a vector of $n_{3}$ regression coefficients, which reflect the direct impact of $n_{3}$ alternative measures of FSD on economic growth.

$\mathbf{B}_{2}^{\prime}=$ a vector of $n_{2}$ regression coefficients, which reflect the indirect impact, or interaction, between $\mathrm{n}_{2}$ external factors and $\dot{F}_{l t}$.

$\mathbf{B}_{\mathbf{4}}{ }^{\prime}=$ a vector of $n_{4}$ regression coefficients, which reflect the indirect impact of a given change in $\mathrm{n}_{4}$ alternative FSD measures on the marginal relationship between $F_{l t}$ and economic growth.

$i=$ country $i$

$t=$ year $t$

$u_{i t}=$ normally distributed error term

As stated above, the direct and indirect external effects hypotheses are tested by using equation (3), where the estimated set of regression coefficients $\left(\mathbf{B}_{\mathbf{1}}{ }^{\prime}\right)$ represent a test of the direct effect hypothesis and $\mathbf{B}_{\mathbf{2}}{ }^{\prime}$ measures the indirect impact of these external factors on the relationship between $\operatorname{FSD}\left(\dot{F}_{l, t}\right)$ and economic development. $\mathbf{B}_{\mathbf{4}}{ }^{\prime}$ is a vector of regression coefficients which measure the indirect impact of alternative FSD measures on the relationship between FSD $\left(\overrightarrow{F_{l, t}}\right)$ and economic development. Thus, the model implies that various FSD measures can either facilitate or possibly hinder the relationship between traditional intermediation services $\dot{F_{l, t}}$ and economic growth. Equation (3) will be estimated with and without cross-sectional and time period fixed effects. 


\subsection{Alternative measures of FSD}

Levine (2004) argues that further study is needed to define the most appropriate measures of FSD, while Demirguc-Kunt (2006) argues that it is crucial to consider all the relevant factors together in one model. Indicators of FSD that have been used in the literature consist of broad measures of banking activity, such as the provision of private credit (bank loans) and measures of liquidity, such as M2 or M3. King and Levine (1993) criticize sole reliance on liquidity as measured by the monetary aggregates, such as $M 3$. They suggest that $M 3$ is an insufficient measure of FSD and suggest four alternatives measures: 1) the size of the financial system as measured by the ratio of liquid liabilities divided by GDP, 2) the ratio of credit provided by banks relative to total banking sector credit, which includes central bank assets, 3) the ratio of bank assets divided by GDP, and 4) the ratio of private credits provided by banks divided by GDP. Table 2 presents a detailed description of various alternative measures of banking sector development along with the expected sign of their associated regressions coefficients. In certain cases, where two factors may have opposite impacts on a third variable it may not be possible to predict the sign of the regression coefficient on the interaction term formed by the two factors. The ultimate sign will depend upon the relative importance of each factor which may vary over time and under different competitive and regulatory conditions. Thus, in many cases the actual sign is ultimately not a theoretical but an empirical issue.

TABLE 2: Alternative measure of FSD1 ${ }_{i t}$ relevant measures for banking sector development

\begin{tabular}{|c|c|c|c|c|}
\hline $\begin{array}{l}\text { Variable Name } \\
\text { (Expected sign) }\end{array}$ & Definition & $\begin{array}{l}\text { Time } \\
\text { period }\end{array}$ & Range & Countries \\
\hline $\operatorname{DEPGDP}(+)$ & Bank deposits divided by GDP & $1960-2005$ & Continuous & 211 \\
\hline BKLNCB (+) & $\begin{array}{l}\text { Percentage of aggregate domestic non- } \\
\text { financial real sector assets held by } \\
\text { commercial banks divide by the level of } \\
\text { total assets held by both commercial } \\
\text { banks and central banks }\end{array}$ & $1960-2005$ & Continuous & 211 \\
\hline $\operatorname{BKLNGDP}(+)$ & $\begin{array}{l}\text { Commercial banks claims on domestic } \\
\text { non-financial real sector assets divided } \\
\text { by GDP }\end{array}$ & $1960-2005$ & Continuous & 211 \\
\hline $\begin{array}{l}\text { Private Credit } \\
\text { BKLNGDP2 (+) }\end{array}$ & $\begin{array}{l}\text { Private credits by deposit money } \\
\text { (commercial) banks to GDP }\end{array}$ & $1960-2005$ & Continuous & 211 \\
\hline
\end{tabular}

Source: Becketal. (2006)

The following discussion describes the specific legal, regulatory, and technological factors which are included in the model. Table 3 provides additional information regarding data sources, frequency of the data, number of countries for which data is available, and the hypothesized sign. In most cases the regression coefficient is expected to be positive but in a few cases the relationship is expected to be negative.

\subsubsection{Legal factors}

The literature suggests that the legal environment can have a direct impact on the availability of funds. Thus, a variable labelled LEGAL is included which is a comprehensive measure of a number of important legal factors, such as judicial independence, impartial courts, protection of property rights, and freedom from political intervention. 


\subsubsection{Regulatory factors}

Bank deposit insurance protection can provide a degree of trust and financial stability which may contribute to economic growth. On the other hand, deposit insurance may also promote excessive risk-taking which may retard economic growth. Furthermore, market structure theory suggests that while restrictions on banking activity might mitigate any adverse effects of deposit insurance, such restriction may create a less competitive banking environment. Furthermore, public control or ownership of banks often hinders efficient resource allocation and may slow economic growth, while bank privatization, especially foreign ownership, often leads to improved bank management. The following variables are designed to proxy for regulatory factors: (1) DEPOSITINS reflects the deposit insurance coverage measured as a percent of per capita GDP, (2) Bank concentration (BKCONCEN), Net Interest Margin (NIM), and Overhead costs (OHCOSTS) are designed to measure the degree of competition in the banking sector.

The expected sign for BKCONCEN is unclear; if market structure theory holds, a negative coefficient is expected, as more concentrated markets allow banks to extract economic rent, while a positive relationship may exist which supports the efficient firm hypothesis. That is, markets are concentrated primarily because firms are more efficient. In general, negative coefficients for NIM and OHCOSTS are expected, (3) privately owned banks (BKPRIVATI) is a proxy for an effective corporate governance mechanism and efficient bank management; hence, a positive sign is expected, (4) foreign-entry (FGENTRY), as measured by the percentage of foreign owned banks, is expected to have a positive coefficient since it signals the potential for a more open and competitive banking environment, and (5) the index of Bank and Commerce Freedom (BKFREE) is designed to measure restrictions on banking activities, entry, and ownership. A higher score indicates greater bank freedom which may be correlated with faster economic growth. On the other hand, the final effect is unclear since greater bank freedom without suitable regulatory safeguards may encourage excessive risk-taking behaviour and ultimately hinder a country's economic growth.

\subsubsection{Technology factors}

Investment in information and communication technology (ICT) promotes economic growth by increasing productivity and lowering operating costs. In addition, ICT can also accelerate FSD through more efficient bank management plus expanded and more timely information disclosure.

TABLE 3: List of external factors: legal, regulatory, and technological (expected signs on $B_{1}{ }^{\prime}$ and $B_{2}{ }^{\prime}$ shown in parenthesis)

\begin{tabular}{llcccc}
\hline \multicolumn{1}{c}{ Variable name } & \multicolumn{1}{c}{ Definition } & $\begin{array}{c}\text { Time } \\
\text { period }\end{array}$ & Range & Countries \\
\hline $\begin{array}{l}\text { Legal factors } \\
\text { LEGAL (+) }\end{array}$ & $\begin{array}{l}\text { Legal structure and security of } \\
\text { property rights }\end{array}$ & $1970-2003$ & $1-10$ & 123 \\
Regulatory factors & $\begin{array}{l}\text { Insurance coverage dollar amount } \\
\text { DEPOSITINS }\end{array}$ & $1960-2004$ & Continuous & 208 \\
Bank Concentration by per capita. & $\begin{array}{l}\text { The share of total assets of the three } \\
\text { largest banks in the country's banking }\end{array}$ & $1960-2005$ & Continuous & 211 \\
\hline
\end{tabular}




\begin{tabular}{|c|c|c|c|c|}
\hline Variable name & Definition & $\begin{array}{l}\text { Time } \\
\text { period }\end{array}$ & Range & Countries \\
\hline BKCONCEN (-) & system. & & & \\
\hline $\begin{array}{l}\text { Net Interest Margin } \\
\text { NIM (-) }\end{array}$ & $\begin{array}{l}\text { The bank's net interest income divided } \\
\text { by its total interesting-bearing assets. }\end{array}$ & $1960-2005$ & Continuous & 211 \\
\hline $\begin{array}{l}\text { Overhead Costs } \\
\text { OHCOSTS }(-)\end{array}$ & $\begin{array}{l}\text { The bank's overhead costs divided by } \\
\text { total assets. }\end{array}$ & $1960-2005$ & Continuous & 211 \\
\hline BKPRIVAT $(+)$ & $\begin{array}{l}\text { The percentage of total deposits held } \\
\text { in privately owned banks, measured in } \\
\text { deciles. }\end{array}$ & $1970-2003$ & $1-10$ & 123 \\
\hline $\begin{array}{l}\text { Foreign-entry } \\
\text { FGNENTRY }(+)\end{array}$ & $\begin{array}{l}\text { Foreign banks' share of total banking } \\
\text { sector assets measured in deciles. }\end{array}$ & 2003 & $1-10$ & 123 \\
\hline $\begin{array}{l}\text { Bank and Commerce } \\
\text { BKFREE }(+)\end{array}$ & Five broad competitive factors. & $1995-2006$ & $1-5$ & 164 \\
\hline \multicolumn{5}{|l|}{ Technology factors } \\
\hline TECHEXP (+) & $\begin{array}{l}\text { Computer, communications and other } \\
\text { related service exports as a } \\
\text { percentage of total commercial } \\
\text { service exports. }\end{array}$ & $1972-2004$ & Continuous & 208 \\
\hline TECHIMP (+) & $\begin{array}{l}\text { Computer, communications and other } \\
\text { related service imports as a } \\
\text { percentage of total commercial } \\
\text { service imports. }\end{array}$ & $1972-2004$ & Continuous & 208 \\
\hline
\end{tabular}

Source: Economic Freedom of the World, World Bank Data, Beck et al. (2006), Index of Bank and Commercial Freedom

\subsubsection{Data}

Data for the countries listed in Table 4 was taken from the IMF's 2005 World Economic Indicators report. The IMF divides the world into two major groups: advanced economies and emerging markets plus developing countries. This paper concentrates on the group of merging/developing countries. While a total of 146 countries are included in this group, a few countries are not included either because they are not IMF members or because the required data is not available. The data for this study was obtained from the following sources: 1) 2005 World Bank Economic Indicators from 1960 to 2004, 2) the data set from Beck et Al. (2006), 3) Index of Economic Freedom, and 4) the Economic Freedom of the World Index. Because of missing data, the total number of emerging countries included in the analysis is 70 , but the actual number of observations depends upon which model specification is being estimated. Precisely which countries are included in which model (panel) is indicated in the first column, as panel A, B, or C.

TABLE 4: List of emerging and developing countries included in sample $(n=70)$

\begin{tabular}{cl|cl}
\hline Country Code & \multicolumn{1}{c|}{ Country Name } & Country Code & \multicolumn{1}{c}{ Country Name } \\
\hline DZA & Algeria & MDG & Madagascar \\
ATG & Antigua and Barbuda & MWI & Malawi \\
ARG & Argentina & MYS & Malaysia \\
BGD & Bangladesh & MLI & Mali \\
\hline
\end{tabular}




\begin{tabular}{|c|c|c|c|}
\hline BEN & Benin & MRT & Mauritania \\
\hline $\mathrm{BOL}$ & Bolivia & MUS & Mauritius \\
\hline BWA & Botswana & MEX & Mexico \\
\hline BRA & Brazil & MAR & Morocco \\
\hline BFA & Burkina Faso & $\mathrm{MOZ}$ & Mozambique \\
\hline $\mathrm{CHL}$ & Chile & NIC & Nicaragua \\
\hline $\mathrm{CHN}$ & China & $N \varepsilon R$ & Niger \\
\hline COL & Colombia & $N G A$ & Nigeria \\
\hline COM & Comoros & PAK & Pakistan \\
\hline ZAR & Congo, Dem. Rep. & PAN & Panama \\
\hline COG & Congo, Rep. & PNG & Papua New Guinea \\
\hline CRI & Costa Rica & PRY & Paraguay \\
\hline CIV & Cote d'Ivoire & PER & Peru \\
\hline DOM & Dominican Republic & PHL & Philippines \\
\hline$\varepsilon C U$ & Ecuador & RWA & Rwanda \\
\hline EGY & Egypt, Arab Rep. & SEN & Senegal \\
\hline દTH & Ethiopia & ZAF & South Africa \\
\hline GAB & Gabon & LKA & Sri Lanka \\
\hline GMB & Gambia, The & LCA & St. Lucia \\
\hline GHA & Ghana & VCT & $\begin{array}{l}\text { St. Vincent and the } \\
\text { Grenadines }\end{array}$ \\
\hline GRD & Grenada & SWZ & Swaziland \\
\hline GTM & Guatemala & SYR & Syrian Arab Republic \\
\hline HND & Honduras & THA & Thailand \\
\hline HUN & Hungary & TGO & Togo \\
\hline IND & India & Тто & Trinidad and Tobago \\
\hline IDN & Indonesia & TUN & Tunisia \\
\hline IRN & Iran, Islamic Rep. & UGA & Uganda \\
\hline JAM & Jamaica & URY & Uruguay \\
\hline JOR & Jordan & VEN & Venezuela, RB \\
\hline KEN & Kenya & ZMB & Zambia \\
\hline LSO & Lesotho & ZWE & Zimbabwe \\
\hline
\end{tabular}

Source: $\quad$ IMF 2005 World Economic Indicator Report

\section{EMPIRICAL FINDINGS}

As discussed above, the first step is to include broader measures of FSD which go beyond a simple measure of liquidity such as M3 $(\dot{F})$. Table $\mathbf{A}$ in the Appendix shows that the various component measures of FSD are highly correlated. To address this problem, principal components analysis was employed to reduce the number of variables. The final model includes both a broader measure of FSD and at the same time allows for a direct comparison of the current findings with the empirical results reported by Odedokun (1996) and Liang and Reichert (2006). Once the alternative FSD measures included in $F S \dot{D} 1_{l t}$ are obtained by principal 
component analysis, equation (3) is estimated and the adjusted $-R^{2}$ is then used to determine the incremental benefit of including these alternative FSD measures in the model. A unit root test was conducted to test each data series for stationarity. The variable is included in first difference form if the series was determined to be non-stationary. The criteria for how many components to include in the final model is a trade-off based on the Kaiser Criterion test (eigenvalues $>1.0$ ), the Cattell test (ordered eigenvalues screen plots), and the degree of variability explained by these components $(>90 \%$ ). The resulting cutoff point is principal component \#2. The percentage of total variance explained by the first two components labelled $\mathrm{ClBK}$ and $\mathrm{C} 2 \mathrm{BK} 2$ is $94.9 \%$.

Table B in the Appendix presents the principal components results. The first component, ClBK, is interpreted as an index of general banking sector development given its large eigenvector loadings with DEPGDP, BKLNGDP, and BKLNGDP2. DEPGDP captures the deposit services provided by the banking sector, while BKLNGDP and BKLNGDP2 capture the effects of bank lending activities. Thus, CIBK can be viewed as a measure of banking sector "broadening" in the sense that it measures the scale of traditional intermediation services. The second component, C2BK2, has high factor loadings on BKLNCB. Thus, C2BK2 can be interpreted as measuring the level of private sector intermediation as measured by the amount of financial capital provided by commercial banks relative to that provided by public sector central banks. Thus, C2BK2 can be viewed as measuring the "deepening" of the banking sector, since commercial banks may provide more sophisticated risk management services and make more efficient capital allocation decisions than government run central banks. After obtaining scores for each of these five components, a unit root test was employed to examine the stationarity of each component. Both components ( $\mathrm{C} 1 \mathrm{BK}$ and $\mathrm{C2BK2}$ ) were non-stationary in their levels and required first differencing, which is indicated by the placing of a "D" in front of the component name [e.g., $\mathrm{D}(\mathrm{ClBK})]$.

The relevant descriptive statistics and associated correlation matrix are provided in Table $\mathbf{5}$. The results indicate that no major multicollinearity problems exist. This is especially true for $\dot{F}$ and the two alternative FSD measures: $\mathrm{D}(\mathrm{C} 1 \mathrm{BK})$ and $\mathrm{D}(\mathrm{C} 2 \mathrm{BK} 2)$. The empirical results of the basic Odedokun model are presented in Table 6. For comparison purposes, Panel A presents the results when no alternative FSD measure is included. Several general findings are as follows: First, by including both measures of $F S \dot{D} 1_{\imath t}$ in the model, the size of the regression coefficient on $\dot{F}$ is increased from 0.046 in Panel A to 0.116 in Panel B. Second, the adjusted $R^{2}$ is increased after including both alternative FSD measures from $23.7 \%$ to $31.5 \%$ and the associated AIC and SC values are reduced. In addition, the coefficient estimates of the $\dot{L}$ and $\dot{X}$ control variables become substantially smaller in size and/or are reduced in statistical significance, while the coefficient estimate on $I / X$ increases. Therefore, by including the two components of $F S \dot{D} 1_{l t}$ the overall impact of the basic measure of financial sector development $(\dot{F})$ becomes stronger. Furthermore, the principal component $\mathrm{D}(\mathrm{ClBK})$, which represents the broader measure of banking sector development, has a highly significant negative impact on economic growth. This may reflect inefficient resource allocation due to excess growth in liquid liabilities. On the other hand, the second principal component $D(C 2 B K 2)$, which reflects the deepening of financial intermediation, carries a positive regression coefficient, which is significant at the $1 \%$ level. This implies that greater sophistication in banking sector development leads to a faster rate of economic growth. To screen the large number of likely inter-correlated external variables, stepwise regression is used to select individual variables by using the forward inclusion method. A p-value of $0.5 \%$ is used as the inclusion/removal criterion for adding or removing variables. The alternative FSD measures, various external factors and interactive terms are all candidates 
for inclusion in the stepwise model. Thus, the list of twelve potential regressor variables includes the two alternative FSD measures: $[D(C 1 B K)$ and $D(C 1 B K 2)]$, one legal factor (LEGAL), seven regulatory factors (DEPSOITINS, BKCONCEN, NIM, OHCOSTS, BKPRIVAT, FGENTRY, and BKFREE), and two technology factors ( $D(T \varepsilon C H E X P)$ and $D(T E C H I M P))$. The results obtained from the stepwise regression are reported in Table 7. Abbreviations for the countries included in the final model are as follows: ARG, BGD, BRA, CHL, COL, DOM, GTM, HND, HUN, IND, JOR, KEN, MEX, NIC, NGA, PRY, $P E R, P H L, L K A, T T O$, and VEN.

TABLE 5: Descriptive statistics and correlation matrix

\begin{tabular}{|c|c|c|c|c|c|c|c|}
\hline & $\dot{Y}$ & $\dot{L}$ & $I / Y$ & $\dot{X}$ & $\dot{F}$ & $D(C I B K)$ & $D(C 2 B K 2)$ \\
\hline Mean & 0.037897 & 0.023197 & 0.207595 & 0.049 & 0.053157 & 0.056642 & -0.00646 \\
\hline Median & 0.041695 & 0.024226 & 0.200453 & 0.052127 & 0.060265 & 0.057584 & 0.002814 \\
\hline Maximum & 0.332802 & 0.115159 & 0.656996 & 0.717362 & 0.531572 & 1.530173 & 2.694142 \\
\hline Minimum & -0.27508 & -0.0814 & 0.035315 & -0.61221 & -1.05782 & -1.44388 & -2.7135 \\
\hline Std. Dev. & 0.044607 & 0.011123 & 0.071491 & 0.115646 & 0.119803 & 0.274145 & 0.313425 \\
\hline Skewness & -0.6087 & -0.49031 & 1.414496 & -0.05821 & -1.20657 & 0.130211 & -0.87719 \\
\hline Kurtosis & 8.495259 & 22.46725 & 8.031698 & 7.353286 & 12.41308 & 6.29495 & 18.99649 \\
\hline Observations & 1660 & 1660 & 1660 & 1660 & 1660 & 1660 & 1660 \\
\hline Correlation Matrix & $\dot{Y}$ & $\dot{L}$ & $I / Y$ & $\dot{X}$ & $\dot{F}$ & $D(C I B K)$ & $D(C 2 B K 2)$ \\
\hline$\dot{Y}$ & 1 & 0.085553 & 0.176562 & 0.349863 & 0.325785 & -0.06167 & 0.163374 \\
\hline$\dot{L}$ & 0.085553 & 1 & -0.12152 & -0.0131 & 0.035489 & -0.07951 & -0.04428 \\
\hline$I / Y$ & 0.176562 & -0.12152 & 1 & 0.097907 & 0.118283 & 0.172642 & -0.03538 \\
\hline$\dot{X}$ & 0.349863 & -0.0131 & 0.097907 & 1 & 0.139217 & -0.04355 & 0.070171 \\
\hline$\dot{F}$ & 0.325785 & 0.035489 & 0.118283 & 0.139217 & 1 & 0.299711 & -0.01543 \\
\hline$D(C I B K)$ & -0.06167 & -0.07951 & 0.172642 & -0.04355 & 0.299711 & 1 & 0.248314 \\
\hline$D(C 2 B K 2)$ & 0.163374 & -0.04428 & -0.03538 & 0.070171 & -0.01543 & 0.248314 & 1 \\
\hline
\end{tabular}

Source: Own calculations

$\dot{Y}$ : economic growth, $\dot{L}$ : labour force growth, $I / Y$ : the investment/GDP ratio, $\dot{X}$ : real export growth, $\dot{F}$ : liquid liability growth, $D(C I B K)$ : "broadening in banking sector development" component by taking the first difference, $D$ (C2BK2): "deepening in banking sector development" component by taking the first difference. 
TABLE 6: Basic panel regression results: alternative measures of financial sector development (no external factors)

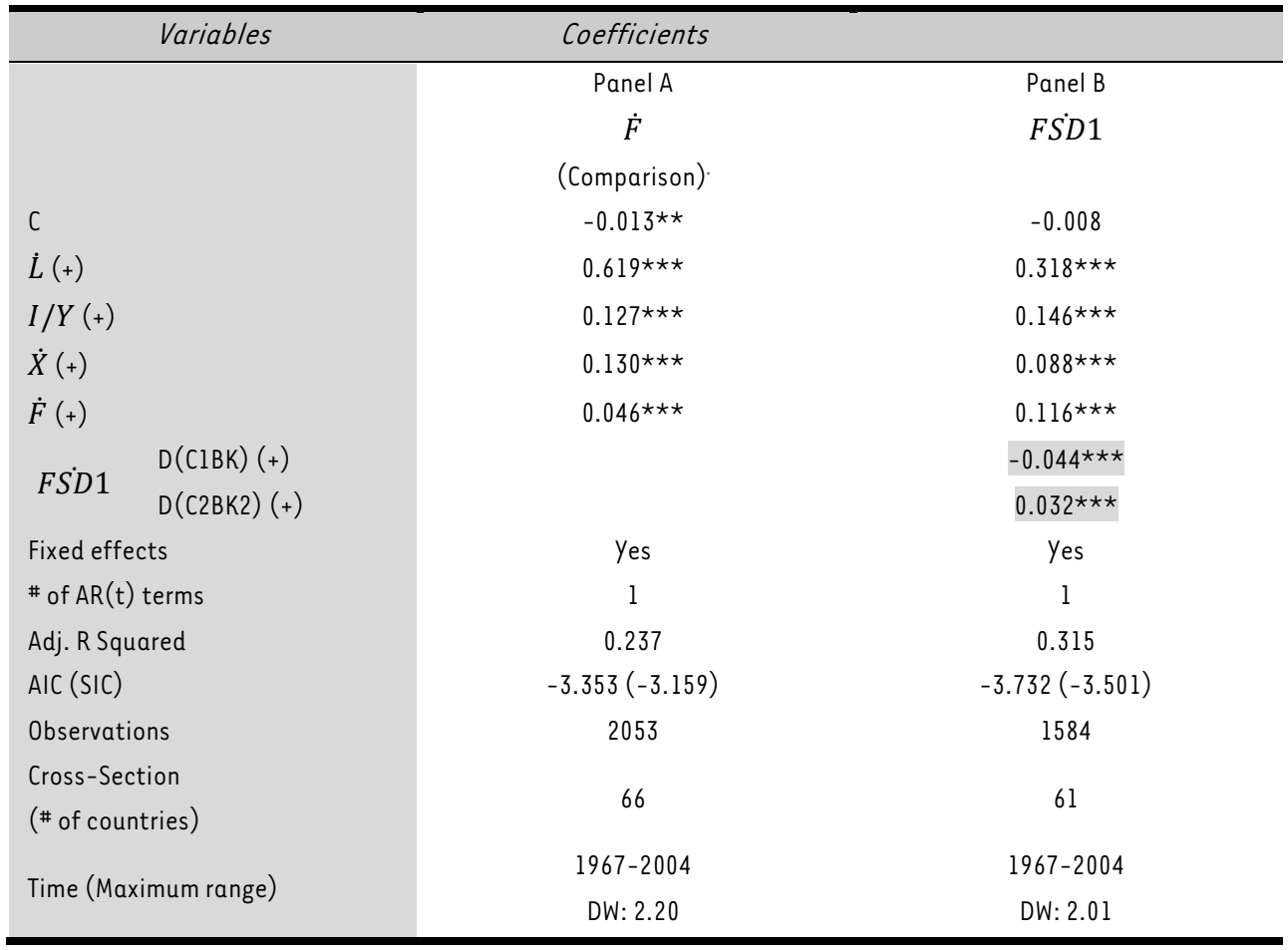

\section{Source: Own calculations}

$\star * \star$ Significant at the 0.001 level. ** Significant at the 0.05 level. * Significant at the 0.10 level.

Expected signs are shown in parentheses.

$\dot{Y}$ : economic growth, $\dot{L}$ : labour force growth, $I / Y$ : the investment/GDP ratio, $\dot{X}$ : real export growth, $\dot{F}$ : liquid liability growth, $D(C I B K)$ : "broadening in banking sector development" component by taking the first difference, $D(C 2 B K 2)$ : "deepening in banking sector development" component by taking the first difference.

Equations:

1) Panel A: $\dot{Y}=\mathrm{C}+$ Countries Dummies $+\dot{L}+I / Y+\dot{X}+\dot{F}+$ error term,

2) Panel B: $\dot{Y}=\mathrm{C}+$ Countries Dummies $+\dot{L}+I / Y+\dot{X}+\dot{F}+\mathrm{D}(\mathrm{C} 1 \mathrm{BK})+\mathrm{D}(\mathrm{C} 2 \mathrm{BK} 2)+$ error term. 
TABLE 7: Expanded panel regression results (direct and indirect effects with external factors)

\begin{tabular}{|c|c|c|c|}
\hline & No Fixed Effects & $\begin{array}{c}\text { Coefficients } \\
\text { Cross-Section Fixed } \\
\text { Effects }\end{array}$ & $\begin{array}{c}\text { Both cross-section and } \\
\text { periods Fixed Effects }\end{array}$ \\
\hline Variables & (1) & (2) & (3) \\
\hline c & -0.042 & -0.038 & -0.048 \\
\hline$\dot{L}(+)$ & $1.145 * \star \star$ & 0.945 & 1.029 \\
\hline$I / Y(+)$ & $0.308 * \star \star$ & $0.488 * \star \star$ & $0.433 * \star$ \\
\hline$\dot{X}(+)$ & $0.099 * \star \star$ & $0.087 \star \star$ & $0.077 *$ \\
\hline$\dot{F}(+)$ & -0.015 & 0.049 & 0.083 \\
\hline \multicolumn{4}{|l|}{ Direct impact: } \\
\hline \multicolumn{4}{|l|}{ FSD 1} \\
\hline $\mathrm{D}($ (C2BK2) $(+)$ & $0.032 * *$ & $0.037 *$ & 0.030 \\
\hline $\mathrm{D}(\mathrm{ClBK})(+)$ & -0.020 & $-0.034 *$ & $-0.037 \star$ \\
\hline \multicolumn{4}{|l|}{ LEGAL } \\
\hline $\operatorname{LEGAL}(+)$ & $0.006 * *$ & 0.003 & 0.009 \\
\hline \multicolumn{4}{|l|}{ REGULATORY } \\
\hline NIM (-) & $-0.243 * \star \star *$ & $-0.642 \star \star \star *$ & $-0.539 \star \star$ \\
\hline FGENTRY (+) & $-0.008 * \star \star$ & $-0.006 * \star \star$ & -0.004 \\
\hline BKPRIVAT $_{n}(+)$ & 0.002 & -0.003 & -0.003 \\
\hline DEPOSITINS (?) & $-0.027 \star \star$ & -0.347 & -0.017 \\
\hline BKFREE (+) & 0.006 & 0.002 & 0.004 \\
\hline \multicolumn{4}{|l|}{ TECHNOLOGY } \\
\hline TECHIMP (+) & $-0.067 \star \star$ & -0.058 & -0.016 \\
\hline TECHEXP $(+)$ & $0.051 *$ & 0.043 & 0.004 \\
\hline \multicolumn{4}{|c|}{ Indirect impact: } \\
\hline \multicolumn{4}{|l|}{ LEGAL } \\
\hline Legal12* $\dot{F}_{(+)}$ & -0.023 & -0.022 & -0.008 \\
\hline \multicolumn{4}{|l|}{ REGULATORY } \\
\hline FGENTRY $\star \dot{F}(+)$ & $0.071 * \star \star$ & $0.067 * \star$ & $0.061^{\star}$ \\
\hline $\mathrm{NIM} \star \dot{F}(-)$ & 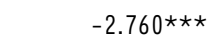 & $-2.357 \star \star$ & $-2.348 *$ \\
\hline $\mathrm{OHCOST} \star \dot{F}_{10}(-)$ & $3.842 \star \star \star$ & 1.262 & 1.142 \\
\hline $\mathrm{BKFRE}^{\star} \dot{F}_{\text {ut }}(+)$ & -0.087 & -0.067 & -0.089 \\
\hline DEPOSITINS* $\dot{F}_{w}(?)$ & $-1.738 * \star$ & -0.893 & -0.520 \\
\hline \multicolumn{4}{|l|}{ TECHNOLOGY } \\
\hline TECHEXP* $\dot{F}_{\sharp}(+)$ & -0.205 & -0.145 & -0.130 \\
\hline Fixed effects & No & Yes (Cross-Country) & $\begin{array}{r}\text { yes (Cross-section } \\
\text { and Period) }\end{array}$ \\
\hline$\#$ of $A R(t)$ terms & 0 & 0 & 0 \\
\hline Adj. R Squared & 0.533 & 0.502 & 0.517 \\
\hline $\operatorname{AIC}(S I C)$ & $-4.375(-3.835)$ & $-4.204(-3.173)$ & $-4.215(-2.988)$ \\
\hline Observations & 110 & 110 & 110 \\
\hline
\end{tabular}




\begin{tabular}{lrrr}
\hline & Coefficients \\
No Fixed Effects & $\begin{array}{c}\text { Cross-Section Fixed } \\
\text { Effects }\end{array}$ & $\begin{array}{c}\text { Both cross-section and } \\
\text { periods Fixed Effects }\end{array}$ \\
\hline $\begin{array}{l}\text { Cross-Section (\# of } \\
\text { countries) }\end{array}$ & 21 & 21 & 21 \\
Time (Maximum range) & $1995-2003$ & $1995-2003$ & $1995-2003$ \\
$\begin{array}{l}\text { Redundant Fixed Effect } \\
\text { Tests (F test) }\end{array}$ & N.A. & P-Value: 0.8496 & P-Value: 0.6148 \\
\end{tabular}

Source: Own calculations

$\star \star \star$ Significant at the 0.001 level. ** Significant at the 0.05 level. * Significant at the 0.10 level. Expected signs are shown in parentheses.

Model equation:

$$
\begin{aligned}
& \dot{Y_{l t}}=b_{0}+b_{1} \dot{L_{l t}}+b_{2}(I / Y)_{i t}+b_{3} \dot{X_{l t}}+b_{4} \dot{F_{l t}}+\mathbf{B}_{\mathbf{1}}{ }^{\prime} \mathbf{E}_{\mathbf{i t}}+\dot{\mathbf{F}}_{\mathbf{i t}} \mathbf{B}_{\mathbf{2}}{ }^{\prime} \mathbf{E}_{\mathbf{i t}}+\mathbf{B}_{\mathbf{3}}{ }^{\prime} \mathbf{F S D}_{\mathbf{i t}}+ \\
& \dot{\mathbf{F}}_{\mathbf{1 t}} \mathbf{B}_{\mathbf{4}}{ }^{\prime} \mathbf{F S D _ { 1 t }}+u_{i t}
\end{aligned}
$$

where,

$\dot{Y_{l t}} \quad=$ economic growth measured as the annual growth rate of real GDP.

$\dot{L_{i t}} \quad=$ labour force growth proxied by the annual rate of growth of the entire population.

$(I / T)=$ gross nominal fixed capital formation (I) divided by nominal GDP (y).

$\dot{X_{l t}} \quad=$ the annual rate of growth rate of real exports of goods and services.

$\dot{F_{l t}} \quad=$ the annual growth rate of liquid liabilities (M3) as used by Odedokun.

$\mathrm{D}(\mathrm{ClBK})=$ "broadening in banking sector development" component by taking the first difference.

$D(C 2 B K 2)=$ "deepening in banking sector development" component by taking the first difference.

LEGAL = a measure of country's legal structure and property rights

DEPOSITINS = deposit insurance coverage divided by per capita GDP

BKCONCEN = combined assets of the three largest banks divided by total banking assets

NIM = banking system's net interest income divided by total interest bearing assets

OHCOST = aggregate value of the banking systems overhead costs divided by total assets

BKPRIVAT = percentage of deposits held in privately owned banks, measured in deciles

FGENTRY = foreign banks' share of total banking sector assets, measured in deciles

BKFREE = Bank Freedom Index regarding the permissibility of mixing bank and commerce

TECHEXP = Computer, communications and other services (\% of commercial service exports)

TECHIMP = Computer, communications, and other services (\% of commercial service imports) 
The number shown after each variable in subscript is the order of that variable in stepwise regression.

The $p$-value for the fixed-effects test indicates that both cross-sectional and time-period fixed effects are redundant. Therefore, the final model is not adjusted for either of the two fixed effects and the relevant results are presented in bold in column (1). The adjusted- $R^{2}$ is $53 \%$. A total of ten direct impact terms are present in the final model, which include the two alternative FSD measures $[D(C 1 B K)$ and $D(C 1 B K 2)]$, legal factor (LEGAL), three regulatory factors (FGENTRY, NIM, OHCOST, BKFREE and DEPOSITINS), and the two technology factors (TECHIMP and TECHEXP). In addition, seven indirect impact terms are included in the final model: the legal factor (LEGAL), five regulatory factors (NIM, FGENTRY, and DEPOSITINS), and one technology factor (TECHEXP). Surprisingly, $\dot{f}$ no longer has a significant impact on the rate of economic growth, while $D$ (C2BK2) has a positive and significant impact. As suggested by Beck, Demirguc-Kunt, and Levine (2001) and La Porta et al. (1997b), LEGAL has a positive direct impact on economic growth at the $5 \%$ level of significance. Consistent with the structure-conduct-performance model, NIM indicates both a strongly significant negative direct impact $(-0.243)$ and a strong negative indirect impact $(-2.760)$. The results for foreign bank entry are mixed, as the coefficients of FGENTRY suggest a negative direct impact on economic growth at the $1 \%$ level, but a positive indirect impact. Consistent with Barth et al. (2004), the role of deposit insurance has a "dark side", as banks can exploit this insurance by taking on excessive risk, which may retard economic growth. Thus it is not surprising that the deposit insurance variable, DEPOSITINS, has both a negative direct and indirect impact on economic growth at the $5 \%$ level. Somewhat surprising, overhead costs (OHCOSTS) have a positive indirect impact on the relationship between $\dot{F}$ and economic growth at the $1 \%$ level. Furthermore, developing countries such as South Korea, which have a strong technology export sector, have experienced dramatic economic growth. Thus it is not surprising to find that the ICT export variable (TECHEXP) has a significant positive direct impact on growth, while TECHIMP has a significant but negative impact. Finally, as predicted by Beck, Demirguc-Kunt, and Levine (2001), including both direct and indirect impact terms for each of several alternative FSD measures along with a number of important external factors, the impact of $\dot{F}$ on economic growth now becomes insignificant.

These results provide evidence that more sophisticated measures of FSD along with important external factors is needed when modelling the relationship between the financial sector and economic development. For example, the negative coefficient on the interaction term $\mathrm{NIM}^{\star} \dot{F}$ provides evidence that a larger but less competitive banking sector can hinder economic growth in emerging/developing countries. Furthermore, the positive coefficient on the interaction variable FGENTRY $* \dot{F}$ provides evidence that a larger banking sector which is open to foreign competition promotes economic growth. The negative coefficients on both DEPOSITINS and the interaction term DEPOSITINS $* \dot{F}$ provides evidence that in emerging countries, a higher percentage of deposit insurance has the potential to generate excessive levels of risk (moral hazard) and constrains economic growth. Surprisingly, the interaction of overhead costs and liquidity $($ OHCOSTS $* \dot{F}$ ) has a highly significant positive impact on economic growth. This result may possibly be explained on the basis that high overhead labour costs reflect a labourintensive production approach, which promotes employment and income.

\section{CONCLUSION}

As discussed in the literature review section, Levine (2004) emphasizes the need to carefully 
identify appropriate measures of financial sector development (FSD), and Demirguc-Kunt (2006) argues that it is crucial to consider all the relevant factors, including a variety of external factors, together in one model. While economic theory might suggest that a more comprehensive measure is preferable to a more narrow definition, the precise definition employed in an empirical study may be conditioned by the scope and detail of the data set being employed. Hence, in this study we have included several alternative measures of FSD and do in fact find that the more comprehensive measures yield superior results. Thus, the empirical results suggest three major conclusions. First, by including a range of alternative financial sector development measures and a variety of external policy-related factors in the model the importance of basic narrowly defined liquidity services, as measured by $M 3$, becomes less important for emerging countries. This suggests that a more comprehensive measure of financial sector development is needed. This conclusion is supported by the positive and statistically significant impact of the principal component factor (C2BK2), which measures the "deepening" of banking sector development. Furthermore, by including the impact of external factors on the economic growth model, the direct influence of liquid liabilities $(\dot{F})$ is no longer statistically significant. At the same time, these basic liquidity services continue to produce both positive and negative indirect effects when they interact with various competitive and regulatory factors, such as foreign bank entry FGENTRY $(+)$, net interest margin NIM(-), overhead costs $\operatorname{OHCOSTS}(+)$, and deposit insurance DEPOSITINS(-).

Second, the empirical results suggest that while a basic level of deposit insurance protection might prove stabilizing for emerging economies, excessive levels of insurance may promote undue risk. The ultimate impact of deposit insurance can perhaps be explained by differences in the level of banking sector development, the autonomy and effectiveness of bank supervisors, and the ownership structure of the banking sector. Third, several competitive market structure and regulatory variables designed to measure efficiency in the intermediation process, such as net interest margin (NIM), and managerial efficiency as measured by overhead costs (OHCOSTS), are found to have a statistically significant, and in certain cases, unexpected impact. For example, higher levels of overhead costs have a surprising positive impact on economic growth. This possibly suggests that emerging countries may structure and regulate their banking sector to promote maximum employment and income by encouraging extensive labour-intensive branch banking networks for example. On the other hand, lack of competition in the intermediation process, as measured by the banking system's net interest margin (NIM), has both a strong negative direct and indirect impact on economic growth. Alternatively, more liberal foreign bank entry (FENTRY) appears to indirectly promote economic growth. In terms of the legal environment, the importance of a strong competitive legal system, as measured by the legal freedom index, has the expected positive impact. These findings are consistent with Cheng and Degryse (2010), who found that reforms and deregulation regarding market entry into the Chinese banking sector have contributed to local economic growth.

The paper contributes to the literature in a number of important ways. First, the findings are consistent with a growing body of literature which indicates that financial sector development needs to be broadly defined and that a wide range of economic, competitive, legal and regulatory factors need to be explicitly considered. Secondly, the study finds that many policyrelated decisions that countries make can have intended and unintended consequences. For example, by eliminating restrictions regarding foreign bank entry into the financial markets more rapid economic growth can be generated. Consistent with Barth et al. (2001a, 2004), our findings suggest that while deposit insurance is intended to stabilize the banking sector, excessive risk-taking induced by overly generous levels of deposit insurance can discourage 
investment and slow economic growth. These findings receive additional support from the recent global financial crises, where many loosely regulated bank and non-bank financial institutions operating in fragmented financial markets introduced an excessive level of risk into the global economy. Thus, while previous studies have identified and modelled individual external factors, this study is the first study to link, in a rigorous and comprehensive way, alternative measures of financial sector development and a wide range of external factors with economic growth.

\section{LIST OF REFERENCES}

Barth, J., Caprio.G. Jr., \& Levine. R. (200la). Banking system around the global: Do regulation and ownership affect performance and stability? Milken Institute: University of Chicago Press.

Barth, J., Caprio, G. Jr., \& Levine, R. (200lb). The regulation and supervision of bank around the world: a new database. Brookings Institutions Press: Brookings-Wharton Papers on Financial Services.

Barth, J., Caprio, G. Jr. \& Levine, R. (2004). Bank regulation and supervision: what work best? Journal of Financial Intermediation, 13(2), pp. 205-248.

Beck, T. \& De la Torre, A.(2007). The Basic Analytics of Access to Financial Services. Financial Markets, Institutions and Instruments, 16(2), pp. 79-117.

Beck, T. \& Demirguc-Kunt, A. (2008). Access to finance - An unfinished agenda. World Bank Economic Review, 22(3), pp. 383-396.

Beck, T., Demiguc-Kunt, A. \& Levine, R. (2001). Legal theories of financial development. Oxford Review of Economic Policy, 17(4), pp. 483-501.

Beck, T., Demirguc-Kunt, A. \& Martinex Peria, M. (2007). Reaching Out: Access to and Use of Banking Services across Countries. Journal of Financial Economics, 85, pp. 234-266.

Beck, T., Demirguc-Kunt, A. \& Martinex Peria, M. (2008). Banking services for everyone? Barriers to bank access and use around the world. World Bank Economic Review, 22(3), pp. 397-430.

Beck, T., Demirguc-Kunt, A. \& Levine, R. (2003). Law and finance: why does legal origin matter? Journal of Comparative Economics, 31(4), pp.635-675.

Beck, T., Demiguc-Kunt, A \& Levine, R. (2006). Bank concentration, competition, and crisis: First results. Journal of Banking and Finance, 30(5), pp.1581-1603.

Beck, T., Levine R, \& Loayza, N. (2000). Finance and the source of growth. Journal of Financial Economics, 58(1,2), pp. 261-300.

Beck, T. \& Levine, R. (2002). Industry growth and capital allocation: does having a market-or bankbased system matter? Journal of Financial Economics, 64, pp.147-180.

Boubakri, N., Cosset, J., Fischer, K. \& Guedhami, 0. (2005). Privatization and bank performance in developing countries. Journal of Banking and Finance, 29(8-9), pp. 2015-2041.

Capiro, G. \& Levine, R. (2002). Corporate governance of banks: Concepts and international observation. Paper presented at the Global Corporate Governance Forum research Network meeting, April, 2002.

Cheng. X. \& Degryse, H. (2010). The Impact of Bank and Non-Bank Financial Institutions on Local Economic Growth in China. Journal of Financial Services Research, 37, pp. 179-199. 
Clarke, G., Cull, R. \& Shirley, M. (2005). Banking privatization in developing countries: a summary of lessons and findings. Journal of Banking and Finance, 29, pp. 1905-1930.

Classens, S. \& Klingebiel, D. (2000). Competition and scope of activities in financial services. Washington DC: World Bank.

Culla,R. \& Spreng, C. (2011). Pursuing efficiency while maintaining outreach: Bank privatization in Tanzania. Journal of Development Economics, 94, pp.254-261.

Demirguc-Kunt, A. \& Maksimovic, V. (2002). Funding growth in bank-based and market-based financial system: evidence from firm-level data. Journal of Financial Economics, 65(3), pp. 337-363.

Demirguc-Kunt, A. \& Detragiache, દ. (2002) Does deposit insurance increase banking stability? An empirical investigation. Journal of Monetary Economics, 49(7), pp.1373-1406.

Demirguc-Kunt, A. (2006). Finance and Economic Development: Policy Choice for Developing Countries, Working Paper.

Ding, S. \& Knight, J. (2009). Can the augmented Solow model explain China's remarkable economic growth?: A cross-country panel data analysis. Journal of Comparative Economics, 37(3), pp. 432-452.

Fu, X. \& Heffernan, S. (2009). The effects of reform on China's bank structure and performance. Journal of Banking \& Finance, 33(1), pp. 39-52.

Gerschenkron, A. (1962). Economic Backwardness in Historical Perspective: A book of Essays. Cambridge, Mass.: Belknap Press of Harvard University Press.

Houben, A. \& Kakes, K. (2002). ICT innovation and economic performance: the role of financial intermediation. Kyklos, 55(4), pp. 543-562.

Jeong, H., \& Townsend, R. (2007). Sources of TFP growth; occupational choice and financial deepening. Economic Theory, 32(1), pp. 179-221.

King, R. \& Levine, R. (1993). Finance and Growth: Schumpeter might be right. The Quarterly Journal of Economics, 108(3), pp. 718-737.

La Porta, R., Lopez-De-Silanes, F. \& Shleifer, A. \& Vishny, R. (1997a). Trust in large organization. American Economic Review, Papers and Proceedings, 87 (2), pp. 333-338.

La Porta, R., Lopez-De-Silanes, F., Shleifer, A. \& Vishny, R. (1997b).Legal determinants of external finance. Journal of Finance, 52(3), pp. 1131-1150.

La Porta, R., Lopez-De-Silanes, F., Shleifer, A. \& Vishny, R. (1998). Law and finance. Journal of Political Economy, 106(6), pp. 1113-1155.

La Porta, R., Florencio, R., Lopex-De-Silanes, F. \& Shleifer, A. (2002). Government ownership of banks. Journal of Finance, 57(1), pp. 265-301.

Levine, $R$ (1998). The legal environment, banks, and long-run economic growth. Journal of Money, Credit and Banking, 30(3), pp. 598-613.

Levine, R (1999). Law, Finance and economic growth. Journal of Financial Intermediation, 8(1,2), pp. 36-67.

Levine, R. (2001). International financial liberalization and economic growth. Review of International Economics, 9(4), pp. 688-702.

Levine, R. (2002). Bank-based or market-based financial systems: which is better? Journal of Financial Intermediation, 11(4), pp. 398-428. 
Levine, R. (2004). Finance and Growth: Theory and Evidence, National Bureau of Economic Research, Working Paper Series 10766, September.

Levine, R., Loayza, N. \& Beck, T. (2000). Financial intermediation and growth: causality and causes. Journal of Monetary Economics, 46(1), pp. 31-77.

Levine, R. \& Zervos, S. (1998). Capital control liberalization and stock market development. World Development, 26(7), pp. 1169-1187.

Liang, H. \& Reichert, A. (2006). The Relationship between Economic Growth and Banking Sector Development. Banks and Bank Systems, 2, pp. 19-35.

Liang, H. \& Alan Reichert, A. (2007). Economic Growth and Financial Sector Development.

International Journal of Business and Finance Research, 1(1), pp. 68-78.

Philips, P. (2007). Some empirics on economic growth under heterogeneous technology. Journal of Macroeconomics, 29(3), pp. 455-469.

Megginson, W. \& Sutter, N. (2006). Privatisation in Developing Countries. Corporate Governance: An International Review, 14(4), pp. 234-265.

Otchere, I. (2009). Competitive and value effects of bank privatization in developed countries. Journal of Banking \& Finance, 33(12), pp. 2373-2385.

Odedokun, M. (1996). Alternative Econometric Approaches for Analyzing the Role of the Financial Sector in Economic growth: Time-Series Evidence from LDCs. Journal of Development Economics, 50, pp. 119-146.

0ECD. (2000). A new economy? The changing role of innovation and information technology in growth, Paris, France.

0ECD. (2001). The new economy: beyond the hype, Financial report on the 0ECD growth project, Paris, France.

O'Mahony, M. \& Vecchi, M. (2005). Quantifying the Impact of ICT Capital on Output Growth:

A Heterogeneous Dynamic Panel Approach. Economica, 72(288), pp. 615-633.

Patrick, H. (1966). Financial Development and Economic Growth in Underdeveloped Countries. Economic Development and Culture Change, 14, January, pp. 174-189.

Rajan, R. \& Zingales, L. (2001). Financial Systems, Industrial Structure, and Growth. Oxford Review of Economic Policy, 17(4), pp. 467-482.

Reichert, A. (1995). The Impact of PCs on the Financial Management of Large Corporations. Information Strategy: The Executive's Journal, 11(3), pp. 35-41.

Reichert, A., Wall, L. \& Liang, H. (2008). The Integration of Banking and Commerce: Part II - Risk And Return Using Efficient Portfolio Analysis. Economic Review, 93(2), pp. 1-14.

Schumpeter, J. (1911). The theory of economy development. Cambridge: Harvard University Press. Shleifer, A. \& Vishny, R. (1986). Large shareholders and corporate control. Journal of Political Economy, 94(3), pp. 461-489.

Shleifer, A. \& Vishny, R. (1998). The Grabbing Hand: Government pathologies and their cures. Cambridge: Harvard University Press.

Stiroh, K. (1999). Is there a new economy? Challenge, 42, pp.82-101. 
Stiroh, K. (2002). Are ICU Spillovers driving the new economy? Review of Income and Wea/th, 48(1), pp. 33-57.

Stulz, R. (2000). Financial structure, corporate finance and economic growth. International Review of Finance, 1(1), pp. 11-38.

Studenmund, A. (2001). Using econometrics: a practical guide, $4^{\text {th }}$ edition. Chicargo, Illinois:Addison Wesley Longman, Inc.

Wall, L., Reichert, A. \& Liang, H. (2008). The Integration of Banking and Commerce: Part I - The Likely Outcome of Eliminating the Barrier. Economic Review, 93(1), pp. 1-16. 


\section{APPENDIX A}

Table A: Financial development correlation matrix

\begin{tabular}{crrrr}
\hline & $D E P G D P$ & $B K L N C B$ & $B K L N G D P$ & $B K L N G D P 2$ \\
$D E P G D P$ & 1 & & & \\
$B K L N C B$ & 0.31758 & 1 & 1 & \\
$B K L N G D P$ & 0.904824 & 0.36961 & 0.940253 & 1 \\
$B K L N G D P 2$ & 0.839261 & 0.415079 & \\
\hline
\end{tabular}

\section{Source: Own calculations}

DEPGDP: Bank deposits divided by GDP

BKLNCB: Percentage of aggregate domestic non-financial real sector assets held by commercial banks divided by the level of total assets held by both commercial banks and central banks.

BKLNGDP: Commercial banks claims on domestic non-financial real sector assets divided by GDP

BKLNGDP2: Private credits by deposit money banks to GDP

Table B: Principal Components Analysis

Eigenvalues: $($ Sum $=4$, Average $=1)$

$\begin{array}{cccccc}\text { Number } & \text { Value } & \text { Difference } & \text { Proportion } & \text { Cumulative } & \text { Cumulative } \\ 1 & 2.99372 & 2.191034 & 0.7484 & 2.99372 & \text { Proportion } \\ 2 & 0.802686 & 0.644266 & 0.2007 & 3.796406 & 0.7484 \\ 3 & 0.15842 & 0.113247 & 0.0396 & 3.954826 & 0.9491 \\ 4 & 0.045174 & & 0.0113 & 4 & 1\end{array}$

Eigenvectors (loadings):

\begin{tabular}{|c|c|c|c|c|}
\hline Variable & $P C 1$ & $P C 2$ & $P C 3$ & $P C 4$ \\
\hline$D E P G D P$ & 0.53577 & -0.23844 & 0.759821 & 0.280659 \\
\hline$B K L N C B$ & 0.304439 & 0.947877 & 0.091229 & -0.02287 \\
\hline$B K L N G D P$ & 0.560512 & -0.18366 & -0.16054 & -0.7914 \\
\hline$B K L N G D P 2$ & 0.553257 & -0.10461 & -0.62336 & 0.542575 \\
\hline
\end{tabular}

\section{Source: Own calculations}

DEPGDP: Bank deposits divided by GDP

BKLNCB: Percentage of aggregate domestic non-financial real sector assets held by commercial banks divided by the level of total assets held by both commercial banks and central banks.

BKLNGDP: Commercial banks claims on domestic non-financial real sector assets divided by GDP

BKLNGDP2: Privates credits by deposit money bank to GDP 
EXPLORING THE FINANCE AND GROWTH RELATIONSHIP FOR EMERGING MARKET ECONOMIES 